\title{
Distribution and resistance of pathogens in liver transplant recipients with Acinetobacter baumannii infection [Expression of concern]
}

\author{
Gao F, Ye Q, Wan Q, Liu S, Zhou J. Distribution and \\ resistance of pathogens in liver transplant recipients with \\ Acinetobacter baumannii infection. Ther Clin Risk Manag. \\ 2015;11:501-505.
}

The Editor-in-Chief and Publisher of Therapeutics and Clinical Risk Management wish to issue an Expression of Concern for the published article.

Concerns have been raised that the study described in the article did not adhere to ethical guidelines as outlined in the Declaration of Helsinki and the Declaration of Istanbul and guidance from the World Health Organization and the World Medical Association regarding the source of transplanted human organs. Specifically, the British Medical Journal Open (BMJ Open) published an article highlighting many papers in which there is concern that transplanted organs were harvested from executed prisoners in China.
In response to these concerns we contacted the authors to clarify the source of the transplanted organs received by the patients described in their study. However, despite multiple attempts to contact the authors and their institutions, no response was received.

The Editors of Therapeutics and Clinical Risk Management would like to alert readers of this. We will provide an update if we receive any further information.

Therapeutics and Clinical Risk Management publishes research adhering to internationally accepted ethical standards and is committed to upholding the Declaration of Helsinki and Declaration of Istanbul. Dove Medical Press endorses the ethics guidelines described by the World Health Organization (WHO) and the World Medical Association (WMA).
Therapeutics and Clinical Risk Management

\section{Publish your work in this journal}

Therapeutics and Clinical Risk Management is an international, peerreviewed journal of clinical therapeutics and risk management, focusing on concise rapid reporting of clinical studies in all therapeutic areas, outcomes, safety, and programs for the effective, safe, and sustained use of medicines. This journal is indexed on PubMed Central, CAS,

\section{Dovepress}

EMBase, Scopus and the Elsevier Bibliographic databases. The manuscript management system is completely online and includes a very quick and fair peer-review system, which is all easy to use. Visit http://www.dovepress.com/testimonials.php to read real quotes from published authors. 